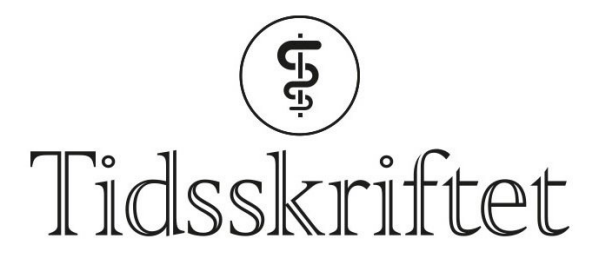

DEN NORSKE LEGEFORENING

\title{
Pensjonistdager med Olav Duun
}

INTERVJU

JANNIKE REYMERT

E-post: jannike.reymert@gmail.com

Da Jostein Holmen rundet 60 følte han behov for å øve på pensjonisttilværelsen og kjøpte seg hytte. Da han nærmet seg 70, dristet han seg til å gå tur med kona midt i arbeidstiden.

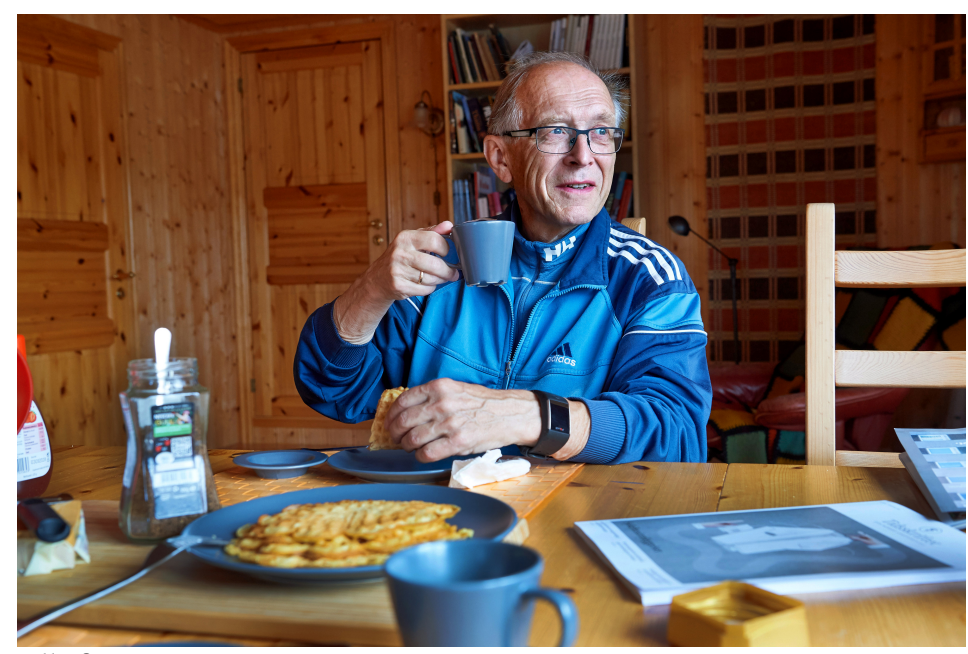

Alle foto: Bjørn Tore Ness

- Etter hvert klarte vi å gå lange turer uten å få dårlig samvittighet, sier han stolt.

Når han ikke gikk tur, begynte han å nylese Olav Duuns romaner.

Interessen for Duuns forfatterskap ble vakt allerede i barndommen.

- Jeg husker godt da jeg som 12-åring hørte Toralf Sandøs opplesningsserie av seksbindsverket Juvikfolket på namdalsdialekt. Det var andaktsstemning i familien, vi satt musestille rundt radioen og lyttet. Duun har fulgt meg siden, men da jeg var i full jobb ble tiden for knapp til å fordype meg i hans litteratur.

Med sine doktorøyne oppdaget han at Duuns romaner har mange og lange beskrivelser av sykdom og uhelse.

- Det hadde jeg ikke lagt merke til før. Duun er kjent for sine skildringer av eksistensielle utfordringer, men egentlig er det ikke rart han har så stort fokus på sykdom og død. Det var en del av hverdagen til menneskene på en helt annen måte enn i dag hvor det å ha god helse er normalen. 


\section{Leseverdige sykdomsbeskrivelser}

Olav Duun-sitater er en egen kategori for Duun-entusiaster. I korte setninger ligger lag på lag med livsvisdom, gjerne ispedd humor og ironi. Når Per-Anders ligger på det siste og skal dø av lungebetennelse, sier han: «Ingen sak å døy når det er klårver og månskin! Og va vi itj heldig som har brent før jul?». For i et skikkelig gravøl skulle det selvsagt skjenkes brennevin. «Å døy, sa han med seg sjølv, det må no gå det. Å bli gammal er verre», sier Odin en gang etter å ha besøkt bestemoren.

Vi fordyper oss i Jostein Holmens pasjon for den store namdalske forfatteren mens hans faglige meritter i legelivet må stå på vent. Forskerkarrieren hans fenger mindre enn litteraturstudier med medisinsk tilsnitt.

\section{Jostein Holmen}

Født i Verdal 1947

Cand.med. Universitetet i Oslo 1973

Dr.med. Universitetet i Oslo 1992

Primærlege i Verdal kommune 1975-2000

Helsetjenesteforsker ved HUNT fra 1984

Førsteamanuensis og professor ved NTNU 1996-2017

Leder av HUNT 1984-2008

Ridder av 1. klasse av St. Olavs Orden for innsatsen for norsk folkehelse 2011

Tuberkulose preget samfunnet rundt forrige århundreskifte, og er naturlig nok den vanligste sykdommen i Duuns bøker. - Det er få eller ingen av dagens generasjon av leger som har sett de mange tragiske uttrykkene som denne sykdommen hadde, sier Jostein Holmen og utdyper:

- Det må ha gjort dypt inntrykk på dem som hadde det tett inn på livet. Jeg mener kunnskapen om tuberkulosens herjinger er noe vi bør ta vare på. Vi skal bare noen timer med fly før dette er realiteten den dag i dag. Dessuten kan antibiotikaresistensen utvikle seg til noe som ligner på maktesløsheten man hadde overfor tuberkulosen for hundre år siden.

Duuns første roman, Marjane, kom ut i 1908. Den kan også leses som en historie om tuberkulose.

- Særlig måten han beskriver tabuet rundt tuberkulose på, tror jeg er typisk for denne tiden.

Spanskesyken er rammen for den klassiske scenen i Juvikfolket da Astri blir syk og mannen Laurits og hovedpersonen Odin seiler over fjorden i storm for å hente medisiner. På vei tilbake kullseiler de, men det er bare plass til én på båthvelvet. Odin ofrer seg og drukner, Laurits klarer å komme hjem med medisinen til kona. «Det er vel berre brennvin, men ta det lell», sier Laurits. Hendelsen er lagt til 1918 da det var forbudstid, det vil si at salg av alkohol var forbudt. Legene visste nok at de ikke hadde effektiv medisin å gi og skrev ut brennevin, kanskje mest som trøst.

- Det var på den tid da begrepet «doktorsprit» kom i bruk, forteller Holmen og fortsetter: Vi skal ikke henge ut legenes håndtering, de visste nok inderlig vel at de sjelden kunne gjøre noe for å berge pasientene, men placeboeffekten var nok stor. Legen kom med ro og trøst og ga folk en følelse av at alt som kunne gjøres, ble forsøkt.

Det velter opp kunnskap om Olav Duun når Jostein Holmen får lov å snakke fritt. - Nøden tvang folk til å sette bort barn. Det gjør vondt å lese når mora til Odin må gi fra seg gutten sin, født utenfor ekteskap, fordi hun har giftet seg. På tur over myrene til hans nye hjem er det vanskelig å holde samtalen i gang, og moren spør Odin: «Ka tenkje du på Odin?», og han svarer: «Æ tenkje på at æ e berre sju år».

Vi får begge en klump i halsen, vi har hørt dette mange ganger før, men det er tunge ord å 
svelge.

\section{Kun notiser om «spanska»}

Pensjonisttilværelsen gir ham også tid til å være aktiv i Verdal historielag. Her har han funnet spennende medisinske opplysninger fra tidligere tider. I Verdal døde 53 mennesker av spanskesyken i løpet av et par måneder høsten 1918. Epidemien er omtalt i et par små notiser i lokalavisen.

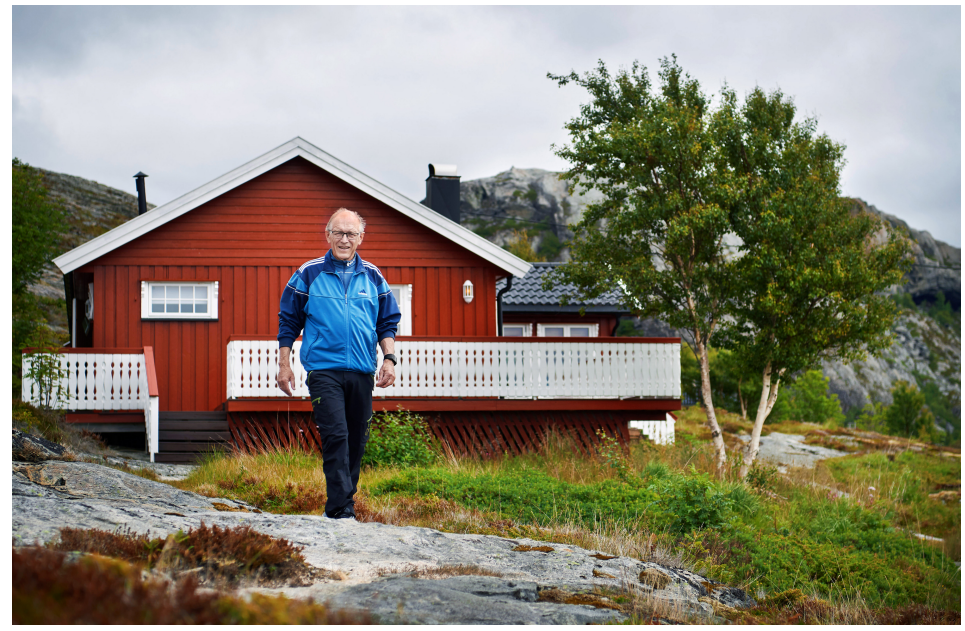

- Når vi vet at det bodde 5 0oo-6 ooo mennesker i kommunen, og de fleste som døde var i alderen 15-35 år, er det utrolig å tenke på at dette ikke skapte kjempeoverskrifter i avisene. Jeg tenker mye på hvordan menneskene opplevde denne katastrofen. Kanskje var det å miste unge i tuberkulose så vanlig at ingen så dette som oppsiktsvekkende. Men det illustrerer hvor forskjellig holdningen til at unge dør var den gangen sammenlignet med i dag. Dette er ikke lenger siden enn at mine foreldre levde på den tiden, sier han ettertenksomt.

\section{Helseundersøkelsen i Nord-Trøndelag}

Jostein Holmen var primærlege i 25 år, i mange år på deltid. Han forteller at forskerkarrieren er et resultat av et feministisk prosjekt.

- I et svakt øyeblikk lovet jeg å være hjemmeværende husfar det året kona ville jobbe i Oslo for å ferdigstille sin spesialitet. Så leste jeg en liten annonse i lokalavisen der professor Peter F. Hjort og fylkeslege Edvard Fjærtoft søkte etter en som kunne se på kvaliteten av blodtrykksbehandlingen i Nord-Trøndelag. De anslo dette som en tre måneders jobb.

Han slår ut med hendene:- Og siden har jeg holdt på med forskning på folkehelse. Etter kort tid fikk vi ideen om en stor befolkningsundersøkelse i fylket. Mange spurte om det var mulig å forske i Nord-Trøndelag, selv Trondheim var litt provinsielt til slikt arbeid i 1980årene. Men for meg var både Oslo og Trondheim så usentralt at dit ville jeg slett ikke flytte.

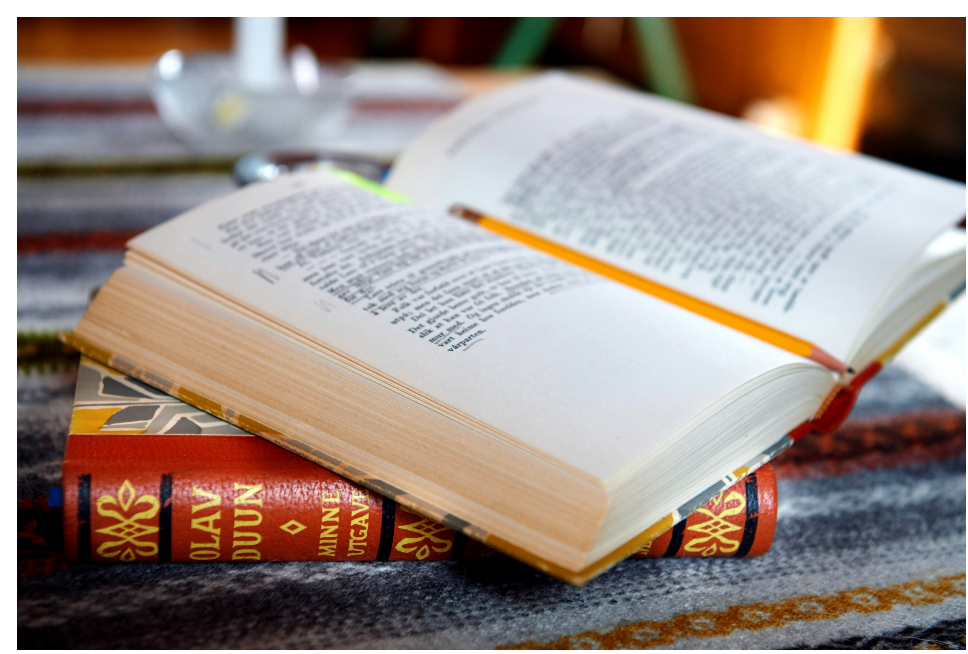


Holmen forteller at professor Hjort slet med å få ham til forstå at han måtte ta doktorgrad hvis han ville fortsette med dette arbeidet.

- Min tanke var at i Verdal trengte ingen doktorgrad.

Kona Turid ble senere en viktig aktør i HUNT, Helseundersøkelsen i Nord-Trøndelag, som leder av Ung-HUNT gjennom mer enn 20 år. Hun ble dermed en av de viktigste kollegene og medarbeiderne hans. Han betoner hennes engasjement som en klar forutsetning for hvordan han har kunnet arbeide.

- Helseundersøkelsen i Nord-Trøndelag har vært en slags «livsstil» for hele familien. Det ser ut til at det har smittet over på neste generasjon: Sønnen vår, som også er lege, tok i 2017 doktorgraden på HUNT-data, og datteren vår, som er klinisk psykolog, brukte Ung-HUNTdata i sin hovedoppgave.

Han har klare tanker om hvorfor HUNT har klart seg så godt.

- Nordtrøndere har sterk eiendomsfølelse til dette. Fylkeskommunen har vært en svært god støttespiller og bidratt både økonomisk og politisk. I tillegg egner fylket seg godt fordi vi er passe store, vi har hatt få politiske stridigheter og ingen store byer som dominerer. Vi har vært billige i drift, og mange har likt at det skjer noe i fylket som ellers dels har vært et fraflyttingsfylke.

- Hva er det viktigste resultatet du ser etter zo års drift?

- Forskning handler om å bygge stein på stein. Vi har hatt et bredt fokus og dermed skapt en forskningsarena der forskere som aldri har samarbeidet før har kunnet møtes. De fleste kliniske fag er representert hos oss. Dessuten kobles medisin og kulturelle forhold og gjør det mulig å klekke ut tverrfaglige ideer. For eksempel er sans for humor og helse et spennende felt. Vi har en teolog som jobber sammen med genetikere. Det er i det hele stor forskningsaktivitet, slik at det nå er ca. 500 pågående HUNT-prosjekter, det publiseres omtrent 100 vitenskapelige artikler årlig. Antallet doktoravhandlinger basert på HUNT-data har passert 200.

De siste årene har molekylærgenetikk kommet sterkt på banen.

- Det har åpnet et stort nytt forskningsfelt der vi egentlig bare har sett begynnelsen ennå.

Han fortsetter ivrig: - En visjon er å komme frem til en mer presis behandling. For eksempel er dagens blodtrykksbehandling på mange måter primitiv, det er som å skyte med hagle. Vi bruker tabletter der bare noen få av hundre har nytte av behandlingen, på den måten at de unngår hjerte- og karsykdom. De andre har i beste fall ingen effekt. Vi vet ikke hvem som har nytte av våre tiltak, men vi vet at vi driver med mye unødvendig behandling. Her kommer genetikken inn, jeg synes det må være lov å ha forventninger til forskningen på dette området.

- Mange lar seg skremme av at genene deres lagres og i verste fall kan misbrukes dersom de faller i gale hender. Hvilke tanker har du om det?

- Etter mitt syn er det ikke riktig å tenke deterministisk om genetisk forsking. Svarene om et menneske kan jo ikke leses direkte av genene, det er kun risiko og sannsynligheter vi kan si noe om. Hva er egentlig forskjellen på å måle folks blodtrykk eller kolesterolnivå og å kartlegge genene deres? spør han retorisk og avslutter:

- Epigenetikken, der genene kan skrus av og på av miljøfaktorer, gjør kunnskap om genetisk disposisjon for sykdom komplisert. Her er det svært mye vi ikke vet ennå.

\section{Dagens medisinske utfordringer}

- Den medisinske verden i dag er totalt forskjellig fra det Olav Duun beskriver for 100 år siden, men den har også endret seg mye fra den gang du var ferdig utdannet lege. Hvilke tanker gjør du deg om medisinens rolle i det moderne samfunnet?

- En av de største utfordringene vi har i dag er de sosioøkonomiske helseforskjellene i 
samfunnet. De ser ut til å bli bare større og større og er i stor grad knyttet opp mot utdanning. HUNT-tall bekrefter dette. Jeg er spent på HUNT 4-undersøkelsen som ruller og går i disse dager, men er redd vi da ser enda større ulikheter enn tidligere. Dette gjør sterkt inntrykk på meg. Min generasjon er vokst opp med en holdning om at det ikke skulle være så store forskjeller mellom folk.

- Det er et tankekors at på tross av den kunnskapen vi har lagt på bordet, skygger politikerne unna å finne effektive tiltak som kan gjøre noe med ulikhetene i helse, sier Holmen. - Vi vet at tiltak på individnivå hjelper lite, det er på gruppenivå man kan skape endringer i en befolkning. Men folkehelse er ingen valgvinner, man får ikke så store resultater i en valgperiode på fire år. Her burde vi fått tverrpolitiske allianser, slik de prøver med oljepolitikk, forsvarspolitikk og i miljøspørsmål.

- Er ikke dette spørsmål du kunne tatt tak i og jobbet med overfor politikerne? Med din bakgrunn burde du jo bli hørt.

- Dette er en oppgave som krever innsats fra mange, jeg rekker nok ikke å gjøre noe i min levetid, sier han og fortsetter: - En av de store «elefantene» $i$ helsepolitikken er alkoholen, som er den underliggende faktoren i mange sykdomsforhold. Ingen tar opp dette, det er nesten et tabuområde. Selv om det selvfølgelig er bakenforliggende årsaker til at folk drikker, er alkoholen i seg selv et så stort folkehelseproblem at tiltak for å få ned totalkonsumet ville gitt en formidabel helsegevinst, avslutter han.

Publisert: 22. november 2018. Tidsskr Nor Legeforen. DOI: 10.4045/tidsskr.18.0754

(C) Tidsskrift for Den norske legeforening 2020. Lastet ned fra tidsskriftet.no 